\title{
Why are PHAC, Health Canada gatekeeping access to NACI?
}

Cite as: CMAJ 2021 September 20;193:E1471. doi: 10.1503/cmaj.1095961

Posted on cmajnews.com on September 2, 2021

H

ealth Canada and the Public Health Agency of Canada (PHAC) stalled media access to the National Advisory Committee on Immunization (NACl) at the same time Canada's chief public health officer suspended regular pandemic briefings and interviews "in light of the election."

Just before the Aug. 15 election call, amid a surging fourth wave of COVID-19, PHAC replaced Dr. Theresa Tam's weekly media briefings with written statements.

Mark Johnson, a spokesperson for PHAC and Health Canada, told CMAJ on Aug. 25 that Tam wasn't taking interviews either, but reporters could "check back after Thanksgiving."

CMAJ had also been trying since July to arrange an interview with $\mathrm{NACl}$ Chair Dr. Shelley Deeks about COVID-19 booster shots and vaccinations for young children, among other evolving issues.

Although $\mathrm{NACl}$ is an independent scientific advisory group, Johnson initially offered a PHAC official to speak for Deeks and later dismissed the interview request "in light of the election." Asked why PHAC and Health Canada were gatekeeping access to independent experts, Johnson claimed a misunderstanding but still put off the interview.

That same day, reporters asked Liberal Leader Justin Trudeau whether the Prime Minister's Office had directed Tam to stop holding briefings. At a campaign stop in British Columbia, Trudeau said that PHAC "makes its decisions about how best to communicate in various situations with Canadians, and they will continue to make sure that Canadians are getting the information they need to stay safe."

During election campaigns, federal agencies act in "caretaker" mode, limiting decisions and communications to those required to keep the government running. The Privy Council Office issued specific advice for the current campaign - none of which seemed to preclude interviews or media briefings about the pandemic.

After the Conservatives called for an investigation into political interference, Tam announced she would hold at least one media briefing before the election to discuss the latest COVID-19 modelling data.

Both $\mathrm{PHAC}$ and $\mathrm{NACl}$ have stressed their independence during the pandemic. But according to a former senior science advisor, a Harper-era reorganization of PHAC that promoted a nonphysician president over the chief public health officer saw the agency subsumed into the general bureaucracy. PHAC now shares a media department with Health Canada, which has, in the past, restricted access to government scientists.

Amir Attaran, a professor of law, epidemiology and public health at the University of Ottawa, said the interruption of pandemic information was disturbing, even though Health Canada and PHAC seem to be backtracking.

"It's not appropriate for there to be any change in communications about scientific matters during a writ period," Attaran told CMAJ. "Even the most meagre change is proof that your science establishment is not politically independent."

\section{Terry Murray, Toronto, Ont.}

Content licence: This is an Open Access article distributed in accordance with the terms of the Creative Commons Attribution (CC BY-NC-ND 4.0) licence, which permits use, distribution and reproduction in any medium, provided that the original publication is properly cited, the use is noncommercial (i.e., research or educational use), and no modifications or adaptations are made. See: https://creativecommons.org/ licenses/by-nc-nd/4.0/ 